\title{
WHEY PROTEIN AERATED GELS AS A NEW PRODUCT OBTAINED USING AMBIENT TEMPERATURE MAGNESIUM AND IRON(II) INDUCED GELATION
}

\author{
M. Tomczyńska-Mleko ${ }^{\mathrm{a} *}$, W. Gustaw ${ }^{\mathrm{b}}$, T. PiersiaK $^{\mathrm{c}}, \mathrm{K}$. Terpilowski ${ }^{\mathrm{d}}$, \\ B. Solowiej ${ }^{\mathrm{e}}$, M. Wesolowska-Trojanowska ${ }^{\mathrm{e}}$ and S. Mleko ${ }^{\mathrm{e}}$

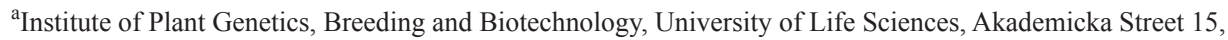 \\ 20-950 Lublin. Poland \\ ${ }^{b}$ Department of Technology of Fruits, Vegetables and Mushrooms, University of Life Sciences, Skromna 8, \\ 20-704 Lublin. Poland \\ ${ }^{c}$ Department of Biochemistry and Biotechnology, Medical University of Lublin, Chodźki 1, 20-093 Lublin. Poland \\ ${ }^{\mathrm{d} D e p a r t m e n t ~ o f ~ P h y s i c a l ~ C h e m i s t r y-I n t e r f a c i a l ~ P h e n o m e n a, ~ M a r i a ~ C u r i e ~ S k ł o d o w s k a ~ U n i v e r s i t y, ~}$ \\ M. Curie Skłodowska Sq. 3, 20-031 Lublin. Poland \\ ${ }^{\mathrm{e}}$ Department of Biotechnology, Human Nutrition and Food Commodity Science, University of Life Sciences,
} Skromna 8, 20-704 Lublin. Poland

(Received 5 March 2013; accepted: 22 April 2013)

\begin{abstract}
The objective of the research was to obtain aerated gels by magnesium and iron(II) ion induced gelation of preheated whey protein isolate dispersions. Preliminary research allowed finding conditions of the $\mathrm{pH}$, protein, and ion concentrations to produce aerated gels capable of holding air bubbles. A novel method applying gelation and aeration process simultaneously was used. Aeration using a laboratory mixer at 2000 r.p.m. produced stronger aerated gels than using a homogenizer at 8000 r.p.m. The gelation process was monitored using an ultrasound viscometer and a constant increase of dynamic viscosity was noted. A different aerated gel microstructure was observed for magnesium and iron(II) induced gels, which probably resulted in differences in the texture and viscosity, as well. The aeration process decreased hardness. In some cases texture parameters correlated with the viscosity measured using an ultrasound viscometer. Aerated whey protein gels could be applied as matrices for food applications or to controlled release of active ingredients.
\end{abstract}

Keywords: dairy, gelation, aeration, protein, whey

Gelation is one of the most important functional properties of whey protein (FoEGEDING, 2007; Gustaw, 2008). Whey protein gels find application in all food processing branches. Recently, more sophisticated application of whey protein gels was reviewed (MLEKO et al., 2010). Whey protein gels, as natural and easily biodegradable products, could be used as a matrix for the release of active ingredients. In our previous research, a novel method of obtaining whey protein aerated gels was presented (TomcZyŃSKA-MLEKo, 2012). Aerated whey protein gels were obtained by simultaneous gelation and aeration of pre-heated solutions. Gelation of whey protein at ambient temperature was induced by calcium ions. The capacity of the gel to retain air bubbles depends on $\mathrm{pH}$, protein concentration, and concentration of inducing ions. Sodium or calcium ion induced or "cold-set" gels obtained from whey protein were extensively investigated (BARbut \& FoEgeding, 1993; BRYAnt \& McClements, 1998; Foegeding, 2007). There is very little research done on "cold-set" gels

\footnotetext{
* To whom correspondence should be addressed.

Phone: +48 (81) 4456896; fax: +48 (81) 4456031; e-mail: martamleko@tlen.pl
} 
obtained by using other cations like magnesium or iron (REMONDETTO et al., 2002; REMONDETTO \& Subirade, 2003; Da Silva \& Delgado, 2009). No results were presented on aerated gels obtained by the addition of the above ions. Aeration of the gel could create a new product with different susceptibility to dissolve in the human stomach. It can be applied to produce gels with controlled active ingredients release rate. They can give a synergistic effect with different active ingredients added to the gel. In literature there is no publication on aerated whey protein gels obtained by iron(II) or magnesium ion induced gelation.

The aim of the research was to investigate the microstructure and texture of magnesium and iron (II) induced aerated whey protein gels.

\subsection{Material}

\section{Materials and methods}

Whey protein isolate (WPI) was purchased from Arla Foods Ingredients (Viby, Denmark). The protein content was determined by the Kjeldahl method and calculating protein as $\mathrm{N} \times 6.25$. The result is the mean of three replications.

\subsection{Aerated gel formation}

WPI dispersions with different protein concentrations $(6.0 ; 6.5 ; 7.0$, or $7.5 \% \mathrm{w} / \mathrm{w})$ were made by hydrating in distilled water. The above protein concentrations were selected based on a preliminary research on the ability of the WPI gels to hold air bubbles, evaluated by sensorial observation. Dispersions were heated in water bath at $80{ }^{\circ} \mathrm{C}$ for $30 \mathrm{~min}$ and after heating immediately cooled down. Magnesium chloride or iron(II) chloride were added in concentrations 30 or $10 \mathrm{mM}$, respectively. Immediately after adding the salt, solutions were foamed for $30 \mathrm{~s}$ at 2000 r.p.m. using Compact Digital Lab Mixer (Cole-Parmer, Montreal, Canada) or at 8000 r.p.m. using H 500 homogenizer (PolEko, Warsaw, Poland). A mixing method for the final samples was selected based on small strain frequency sweeps measurements (at the strain 0.01) performed using RS300 rheometer (ThermoHaake, Karlsruhe, Germany). A parallel plate geometry (35 mm diameter, gap size $2 \mathrm{~mm}$ ) with serrated steel plates was used to limit the sliding effects. The gelation process was monitored using Unipan type 505 ultrasound viscometer (UNIPAN, Warsaw, Poland). Aerated gels were stored for 20 hours at temperature $7{ }^{\circ} \mathrm{C}$, equilibrated at $21^{\circ} \mathrm{C}$ for $1 \mathrm{~h}$, and subjected to evaluation of their properties.

\subsection{Viscosity $\times$ density}

Viscosity $\times$ density in $\mathrm{mPas} \times \mathrm{g} \mathrm{cm}^{-3}$ of the aerated gels was measured using Unipan type 505 ultrasound viscometer (UNIPAN, Warsaw, Poland). Before each measurement, the ultrasound signal level was checked. The measuring probe of the magnetostrictive vibrator was placed entirely in the gel. Induced ultrasound waves were damped by the tested material and the results were displayed as the product of viscosity and density in the units $\mathrm{mPas} \times \mathrm{g} \mathrm{cm}^{-3}$. All measurements were performed in six replications. 


\subsection{Textural properties of the gels}

A two-bite penetration test was performed using the TA-XT2i Texture Analyser (Stable Micro Systems, Godalming, UK). The foamed gel samples prepared in $40 \mathrm{~mm}$ in diameter beakers were analysed using a $10 \mathrm{~mm}$ in diameter steel cylinder probe operated at a crosshead speed of $1 \mathrm{~mm} \mathrm{~s}^{-1}$ and penetration distance of $30 \mathrm{~mm}$. Hardness, adhesiveness, springiness, cohesiveness, and chewiness were evaluated. Hardness was measured as the peak force during the first penetration; adhesiveness represents the work required to pull the plunger from the sample; springiness was measured as the distance of the detected height of the product on the second penetration divided by the original product height; cohesiveness was measured as the work performed during the second penetration divided by the work performed during the first penetration; chewiness is the product of hardness, cohesiveness, and springiness and represents the energy required to chew the sample. Six measurements were carried out for each test.

\subsection{Laser confocal scanning microscopy (LCSM)}

Samples of the gels and aerated gels were cut with surgical scalpel and carefully placed on a microscope glass slide. Preparations were viewed using laser scanning confocal microscope LSCM 510 (Carl Zeiss, Jena, Germany). Images were analysed using the computer software Zeiss LSM 5 Image Examiner (Carl Zeiss, Jena, Germany).

\subsection{Scanning electron microscopy (SEM)}

Samples of the aerated gels were fixed by immersion in $2.5 \%$ glutaraldehyde solution in $0.1 \mathrm{M}$ sodium cacodylate buffer. The samples were dehydrated in serial dilutions of ethanol and acetone and dried at the critical point in liquid carbon dioxide. Preparations were coated with gold using a vacuum evaporator EMITECH K550x (Emitech, Ashford, United Kingdom). Preparations were viewed and photographed using a scanning electron microscope VEGA II LMU (Tescan, Canberra, USA).

\subsection{Average bubble size Turbiscan measurements}

The average bubble size of the aerated gels was evaluated using Turbiscan apparatus (Formulaction, France). The aerated gels were carefully transferred to a flat-bottomed glass cylindrical sample cell. The samples were scanned by a pulsed near infrared light source (wavelength $880 \mathrm{~nm}$ ) and two synchronized detectors were used to collect the transmitted and backscattering lights. The average size of the air bubbles dispersed in the gel was calculated using Turbiscan Lab expert software (Formulaction, France). All measurements were made in triplicate.

\subsection{Statistical methods}

The statistical analysis of results (standard deviation, analysis of variance) was performed using the statistical program STATISTICA 5.0 PL (StatSoft Polska, Warsaw, Poland). The significance of differences between means was determined using the Tukey's test at the confidence level of $\mathrm{P} \leq 0.05$ based on the least significant difference. 


\section{Results and discussion}

Preliminary research on gel aeration method showed that aeration using a mixer at 2000 r.p.m. produced stronger aerated gels than using a homogenizer at 8000 r.p.m., as storage modulus values were higher in the whole range of applied frequency (Fig. 1). These studies demonstrate that the very intensive mixing during aeration by using a homogenizer is not desirable. Mechanical stirrer paddles form the characteristic "vortex", which draws air into the gel and causes intensive aeration with only partial destruction of the formed gel matrix. Homogenizer operated at high speed probably destroys the aggregates of the nascent gel. Therefore, for the preparation of aerated gels, laboratory stirrer equipped with paddles was selected and all the tested samples were prepared using this device. Combinations of protein concentration and $\mathrm{pH}$ at which it was possible to obtain a gel with a texture suitable for holding air bubbles were chosen based on results of preliminary research. For iron(II) ions the conditions were: 7.0, 7.5, and 8.0\% (w/w) of protein at the native $\mathrm{pH} 6.68$. For magnesium ions, in most cases, it was necessary to increase the $\mathrm{pH}$ and the conditions were: $6.0,7.0$, and $8.0 \%(\mathrm{w} / \mathrm{w})$ at $\mathrm{pH} 7.34$ (a $\mathrm{pH}$ value between native 6.68 and 8.0 ), 7\% at $\mathrm{pH} 8.0$, and $7 \%$ at $\mathrm{pH}$ 6.68. Figure $2 \mathrm{~A}$ shows a laser confocal scanning micrograph of aerated gel obtained by $10 \mathrm{mM}$ iron(II) addition. The protein concentration was $7.5 \%$ at $\mathrm{pH} 6.68$. The gel is transparent and a fractal structure of air bubbles is observed, as smaller bubbles are included in larger ones. A different microstructure was observed for an aerated gel obtained by inducing gelation under the influence of magnesium ions at a concentration of $30 \mathrm{mM}$ (Fig. 2B). Protein concentration of the solution was $7 \%$ at a $\mathrm{pH} 7.34$. The gel is more opaque and the aeration created rather single air bubbles. The degree of aeration is also smaller than in the case of iron ions. This was supported by SEM pictures. Figure 2C shows the microstructure of an aerated gel obtained by inducing gelation at room temperature with iron(II) ions at the concentration of $10 \mathrm{mM}, 7.5 \%$ protein, and $\mathrm{pH} 6.68$. The picture shows the cavities inside the air bubble created by smaller air bubbles, which supports a fractal nature of the air bubbles observed at the LCSM picture. Figure 2D shows the SEM microstructure of an aerated gel produced by magnesium ions at a concentration of $30 \mathrm{mM}$ at pH 7.34 and $7 \%$ protein. Aerated gel obtained by inducing gelation using magnesium ions has a very interesting microstructure. This structure is more particulate than in the case of gels induced by iron(II) ions and characteristic imprinted cavities on the surface of the air bubbles are observed. The microstructure of magnesium induced ions is composed of larger particles. This can be explained by the higher ionic strength of the solution with the addition of magnesium ions, but gelling occurred at $\mathrm{pH}$ 7.34 instead of the native $\mathrm{pH}$ (6.68). Higher $\mathrm{pH}$ values create more fine-stranded gel microstructure due to increased repulsion between the negatively charged protein chains (FoEGEDING et al., 2002). However, in this case higher ionic strength probably outweighed the effect of $\mathrm{pH}$ and the resulting gel had more particulate structure compared to the fine-stranded gel prepared under the influence of iron(II) ions (FoEgEDING et al., 1990; STADING et al., 1995; FoEGEDING et al., 2002). Fine-stranded microstructure of iron(II) induced whey protein gels was previously observed by REMONDETTO and co-workers (2002). The average bubble size in aerated gels was measured using Turbiscan apparatus (Table 1). For ferric ion induced gels, increasing the protein concentration to $8.0 \%$ resulted in a sudden increase in average bubble size. It can be caused by the faster gelation process observed at this protein concentration by ultrasound viscosity measurements (Fig. 3). Aeration of a stronger gel caused breaking of the gel matrix to larger microgels, which at the reforming process included larger air bubbles. There was a constant increase in the dynamic viscosity $\times$ density value of the investigated 
gels (Fig. 3). There are no known studies presenting application of the ultrasonic viscometers to monitor gelation process. The values of dynamic viscosity $\times$ density of aerated and nonaerated gels were also measured after $20 \mathrm{~h}$ of storing at $7{ }^{\circ} \mathrm{C}$ and equilibrating to room temperature. In all cases the viscosity of aerated gels was lower than of non-aerated ones (data not shown). The hardness of iron(II) ion induced gels increased with increased protein concentration (Table 2). Aeration decreased the hardness of the gels. In most cases, nonaerated gels were more cohesive. Only in the case of the gel obtained at $\mathrm{pH} 8$ was the aerated form more cohesive. Chewiness of the gels decreased after aeration (Table 2). For the gels obtained by magnesium induced gelation, the hardness of the aerated gels was several times lower than of non-aerated ones (Table 2). There was an optimal protein concentration $(7.5 \%)$ to maximize the hardness of non-aerated and aerated gels. Measured hardness of aerated gels was smaller than of non-aerated gels, as air bubbles create fracture propagation centres. For iron(II) ion induced gels, there was an optimal concentration of protein (7.5\%) to obtain the highest hardness of aerated gels. At smaller protein concentration $(7.0 \%)$ the obtained gel structure was too weak and at higher protein concentration $(8.0 \%)$ the obtained gel was too strong and it could not recover after aeration shearing. The same mechanism was observed previously in heat-induced aerated whey protein gels (ToMCZYŃsKA-MLEKo, 2009; 2010). In some cases, texture parameters correlated with the viscosity measured using an ultrasound viscometer. There was a correlation between springiness and dynamic viscosity $\times$ density of aerated gels obtained by magnesium ion induction [springiness $=0.0039 \times($ viscosity $\times$ density) $\left.+0.8802, \mathrm{R}^{2}=0.81\right]$. Cohesiveness and chewiness of non-aerated gels obtained by iron(II) induced gelation correlated with the viscosity [cohesiveness $=0.0189 \times($ viscosity $\times$ density) $+0.3036, \mathrm{R}^{2}=0.99$; chewiness $=1.8719 \times($ viscosity $\times$ density $\left.)-4.1036, \mathrm{R}^{2}=0.83\right]$. For gels with higher chewiness more energy is needed for the fragmentation of the gel as more energy is needed for overcoming frictional forces between gel particles. Friction forces generated during shearing forces at chewing determine its viscosity. In the most cases aerated gels had higher adhesiveness than non-aerated gels (Table 2). It could be caused by the air bubbles increasing the adhesiveness of the aerated gels to the plunger surface. Aeration process did not cause significant changes in the springiness of the gels.

Table 1. Influence of ion type, protein concentration, and $\mathrm{pH}$ of the gel on the average air bubble size

\begin{tabular}{lc}
\hline $\begin{array}{l}\text { Ion type, } \\
\text { protein concentration, } \\
\text { and pH of the gel }\end{array}$ & $\begin{array}{l}\text { Average bubble } \\
\text { size }(\mathrm{mm})(\mathrm{SD})\end{array}$ \\
\hline $\mathrm{Fe}(\mathrm{II}), 7.0 \%, \mathrm{pH} 6.68$ & $34.2(2.4)$ \\
$\mathrm{Fe}(\mathrm{II}), 7.5 \%$, pH 6.68 & $56.8(3.9)$ \\
$\mathrm{Fe}(\mathrm{II}), 8.0 \%, \mathrm{pH} 6.68$ & $213(22)$ \\
$\mathrm{Mg}(\mathrm{II}), 7.0 \%, \mathrm{pH} 6.68$ & $567(16)$ \\
$\mathrm{Mg}(\mathrm{II}), 6.0 \%, \mathrm{pH} 7.34$ & $43.7(2.1)$ \\
$\mathrm{Mg}(\mathrm{II}), 7.0 \%, \mathrm{pH} 7.34$ & $223(9.0)$ \\
$\mathrm{Mg}(\mathrm{II}), 8.0 \%, \mathrm{pH} 7.34$ & $443(13)$ \\
$\mathrm{Mg}(\mathrm{II}), 7.0 \%, \mathrm{pH} 8.00$ & $574(32)$ \\
\hline
\end{tabular}


Table 2. Texture profile analysis for gels and aerated gels obtained by $\mathrm{Fe}(\mathrm{II})$ and $\mathrm{Mg}$ induced gelation of whey protein isolates at different $\mathrm{pH}$ and protein concentration

\begin{tabular}{|c|c|c|c|c|c|c|c|c|c|c|}
\hline \multirow[t]{2}{*}{$\begin{array}{l}\text { Ion, } \mathrm{pH}, \\
\text { prot.(\%) }\end{array}$} & \multicolumn{2}{|c|}{$\begin{array}{l}\text { Hardness } \\
(\mathrm{G})\end{array}$} & \multicolumn{2}{|c|}{$\begin{array}{l}\text { Adhesiveness } \\
\qquad(\mathrm{G} \times \mathrm{s})\end{array}$} & \multicolumn{2}{|c|}{ Springiness } & \multicolumn{2}{|c|}{ Cohesiveness } & \multicolumn{2}{|c|}{ Chewiness } \\
\hline & gel & aerated & gel & aerated & gel & aerated & gel & aerated & gel & aerated \\
\hline $\begin{array}{l}\mathrm{Fe} \\
6.68,7.0\end{array}$ & $\begin{array}{l}92.3^{\mathrm{b}} \\
(5.1)\end{array}$ & $\begin{array}{l}21.9^{\mathrm{a}} \\
(1.7)\end{array}$ & $\begin{array}{l}65.9^{\mathrm{a}} \\
(3.2)\end{array}$ & $\begin{array}{c}2.18^{\mathrm{a}} \\
(0.22)\end{array}$ & $\begin{array}{c}0.97^{\mathrm{a}} \\
(0.057)\end{array}$ & $\begin{array}{l}0.98^{\mathrm{a}} \\
(0.05)\end{array}$ & $\begin{array}{c}0.44^{\mathrm{a}} \\
(0.03)\end{array}$ & $\begin{array}{l}0.42^{\mathrm{a}} \\
(0.03)\end{array}$ & $\begin{array}{l}43.9^{b} \\
(4.8)\end{array}$ & $\begin{array}{l}8.23^{\mathrm{a}} \\
(0.98)\end{array}$ \\
\hline $\begin{array}{l}\mathrm{Fe} \\
6.68,7.5\end{array}$ & $\begin{array}{c}111.5^{\mathrm{c}} \\
(7.3)\end{array}$ & $\begin{array}{l}45.7^{\mathrm{c}} \\
(2.2)\end{array}$ & $\begin{array}{l}17.7^{\mathrm{b}} \\
(1.0)\end{array}$ & $\begin{array}{l}99.8^{\mathrm{c}} \\
(7.3)\end{array}$ & $\begin{array}{l}1.02^{\mathrm{a}} \\
(0.05)\end{array}$ & $\begin{array}{l}0.94^{\mathrm{a}} \\
(0.03)\end{array}$ & $\begin{array}{l}0.38^{\mathrm{a}} \\
(0.04)\end{array}$ & $\begin{array}{l}0.56^{\mathrm{b}} \\
(0.03)\end{array}$ & $\begin{array}{l}42.6^{\mathrm{b}} \\
(8.8)\end{array}$ & $\begin{array}{l}23.8^{\mathrm{c}} \\
(3.1)\end{array}$ \\
\hline $\begin{array}{l}\mathrm{Fe} \\
6.68,8.0\end{array}$ & $\begin{array}{l}59.9^{\mathrm{a}} \\
(2.4)\end{array}$ & $\begin{array}{l}27.9^{b} \\
(1.8)\end{array}$ & $\begin{array}{c}1.57^{\mathrm{c}} \\
(0.18)\end{array}$ & $\begin{array}{l}14.3^{\mathrm{b}} \\
(0.9)\end{array}$ & $\begin{array}{l}0.92^{\mathrm{a}} \\
(0.06)\end{array}$ & $\begin{array}{l}0.96^{\mathrm{a}} \\
(0.06)\end{array}$ & $\begin{array}{l}0.43^{\mathrm{a}} \\
(0.02)\end{array}$ & $\begin{array}{l}0.52^{\mathrm{a}} \\
(0.02)\end{array}$ & $\begin{array}{l}23.8^{\mathrm{a}} \\
(2.8)\end{array}$ & $\begin{array}{l}14.1^{\mathrm{b}} \\
(1.8)\end{array}$ \\
\hline $\begin{array}{l}\mathrm{Mg} \\
6.68,7.0\end{array}$ & $\begin{array}{l}125.9 \\
(3.2)^{\mathrm{a}}\end{array}$ & $\begin{array}{l}39.7^{\mathrm{c}} \\
(3.1)\end{array}$ & $\begin{array}{c}60.9 \\
(18.5)^{\mathrm{a}}\end{array}$ & $\begin{array}{c}15.7 b^{c} \\
(1.2)\end{array}$ & $\begin{array}{c}0.97^{\mathrm{a}} \\
(0.01)\end{array}$ & $\begin{array}{l}1.02^{\mathrm{b}} \\
(0.02)\end{array}$ & $\begin{array}{c}0.49^{\mathrm{b}} \\
(0.03)\end{array}$ & $\begin{array}{l}0.53^{\mathrm{ab}} \\
(0.02)\end{array}$ & $\begin{array}{l}59.4^{\mathrm{a}} \\
(4.0)\end{array}$ & $\begin{array}{l}21.2^{\mathrm{c}} \\
(1.4)\end{array}$ \\
\hline $\begin{array}{l}\mathrm{Mg} \\
7.34,6.0\end{array}$ & $\begin{array}{c}152.4^{\mathrm{b}} \\
(2,5)\end{array}$ & $\begin{array}{c}16.4 \\
(1.87)^{\mathrm{a}}\end{array}$ & $\begin{array}{c}1.14 \\
(0.15)^{\mathrm{b}}\end{array}$ & $\begin{array}{l}35.4 b \\
(97.4)\end{array}$ & $\begin{array}{c}1.02^{\mathrm{a}} \\
(0.01)\end{array}$ & $\begin{array}{l}0.94^{\mathrm{a}} \\
(0.01)\end{array}$ & $\begin{array}{l}0.82^{\mathrm{d}} \\
(0.04)\end{array}$ & $\begin{array}{l}0.56^{\mathrm{b}} \\
(0.01)\end{array}$ & $\begin{array}{l}127.8^{\mathrm{b}} \\
(27.4)\end{array}$ & $\begin{array}{l}8.57^{\mathrm{a}} \\
(1.51)\end{array}$ \\
\hline $\begin{array}{l}\mathrm{Mg} \\
7.34,7.0\end{array}$ & $\begin{array}{c}170.9^{\mathrm{c}} \\
(4.9)\end{array}$ & $\begin{array}{c}44.1 \\
(4.2)^{\mathrm{c}}\end{array}$ & $\begin{array}{c}2.84 \\
(0.29)^{\mathrm{b}}\end{array}$ & $\begin{array}{l}10.9^{\mathrm{c}} \\
(0.5)\end{array}$ & $\begin{array}{l}0.09^{b} \\
(0.01)\end{array}$ & $\begin{array}{l}1.02^{\mathrm{b}} \\
(0.01)\end{array}$ & $\begin{array}{l}0.72^{\mathrm{c}} \\
(0.03)\end{array}$ & $\begin{array}{l}0.49^{\mathrm{a}} \\
(0.04)\end{array}$ & $\begin{array}{l}133.1^{\mathrm{b}} \\
(21.3)\end{array}$ & $\begin{array}{l}21.8^{\mathrm{c}} \\
(0.6)\end{array}$ \\
\hline $\begin{array}{l}\mathrm{Mg} \\
7.34,8.0\end{array}$ & $\begin{array}{l}276.6^{\mathrm{e}} \\
(12.6)\end{array}$ & $\begin{array}{c}54.0 \\
(4.8)^{\mathrm{d}}\end{array}$ & $\begin{array}{l}4.00^{\mathrm{b}} \\
(0.45)\end{array}$ & $\begin{array}{l}172.0^{\mathrm{a}} \\
(14.9)\end{array}$ & $\begin{array}{l}1.12^{b} \\
(0.03)\end{array}$ & $\begin{array}{l}0.94^{\mathrm{a}} \\
(0.02)\end{array}$ & $\begin{array}{l}0.73^{\mathrm{c}} \\
(0.03)\end{array}$ & $\begin{array}{l}0.52^{\mathrm{ab}} \\
(0.02)\end{array}$ & $\begin{array}{l}220.9^{\mathrm{c}} \\
(27.4)\end{array}$ & $\begin{array}{c}26.25^{\mathrm{d}} \\
(1.5)\end{array}$ \\
\hline $\begin{array}{l}\mathrm{Mg} \\
8.00,7.0\end{array}$ & $\begin{array}{c}213.9^{\mathrm{d}} \\
(6.2)\end{array}$ & $\begin{array}{l}26.4^{b} \\
(1.9)\end{array}$ & $\begin{array}{l}23.3^{b} \\
(4.4)\end{array}$ & $\begin{array}{l}58.2^{\mathrm{a}} \\
(3.1)\end{array}$ & $\begin{array}{c}0.98^{\mathrm{a}} \\
(0.02)\end{array}$ & $\begin{array}{l}0.92^{\mathrm{a}} \\
(0.03)\end{array}$ & $\begin{array}{c}0.32^{\mathrm{a}} \\
(0.02)\end{array}$ & $\begin{array}{c}0.57^{\mathrm{b}} \\
(0.01)\end{array}$ & $\begin{array}{c}61.4^{\mathrm{a}} \\
(16.0)\end{array}$ & $\begin{array}{l}13.7^{\mathrm{b}} \\
(0.6)\end{array}$ \\
\hline
\end{tabular}

Means for the same ion, gel type, and TPA parameter with the same letter are not significantly different from each other $(\mathrm{P}<0.05)$ (in parentheses - standard deviation)

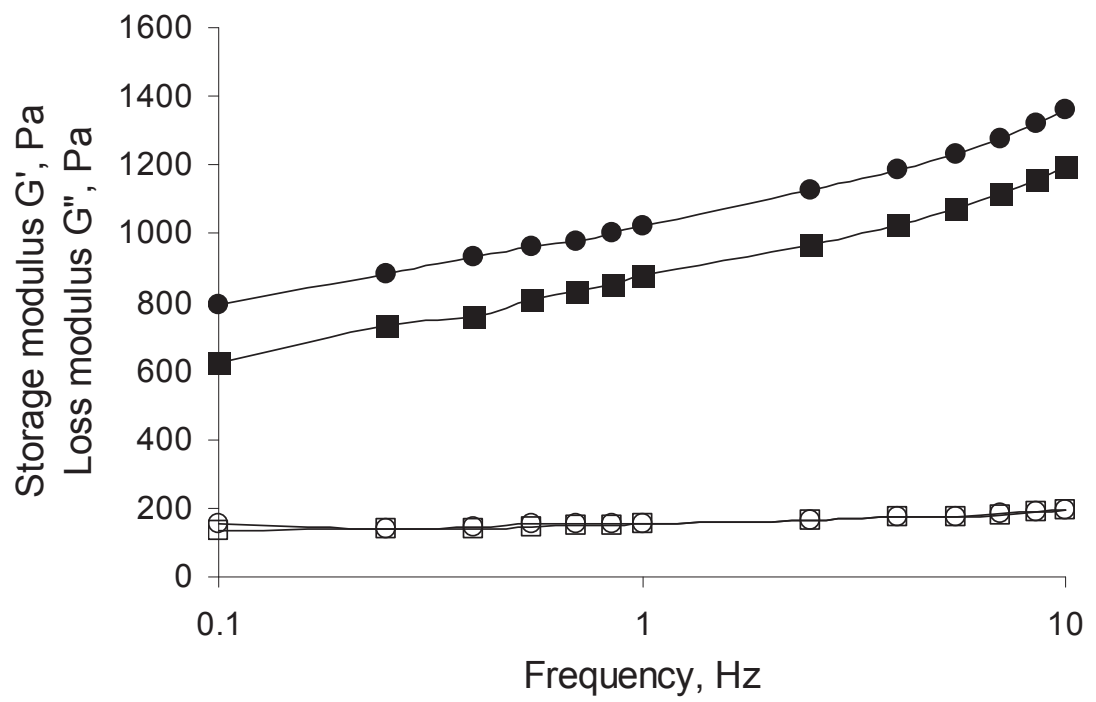

Fig. 1. Influence of an aeration method (m-mixer, h-homogenizer) on the storage and loss moduli of the aerated gels obtained by $30 \mathrm{mM}$ magnesium ion induction. •: G', 7\% protein, $\mathrm{pH} 7.34 \mathrm{~m}$; ○: G”, 7\% protein, $\mathrm{pH} 7.34 \mathrm{~m}$; 口: G', 7\% protein, $\mathrm{pH} 7.34 \mathrm{~h} ; \square:$ G”, 7\% protein, $\mathrm{pH} 7.34 \mathrm{~h}$ 


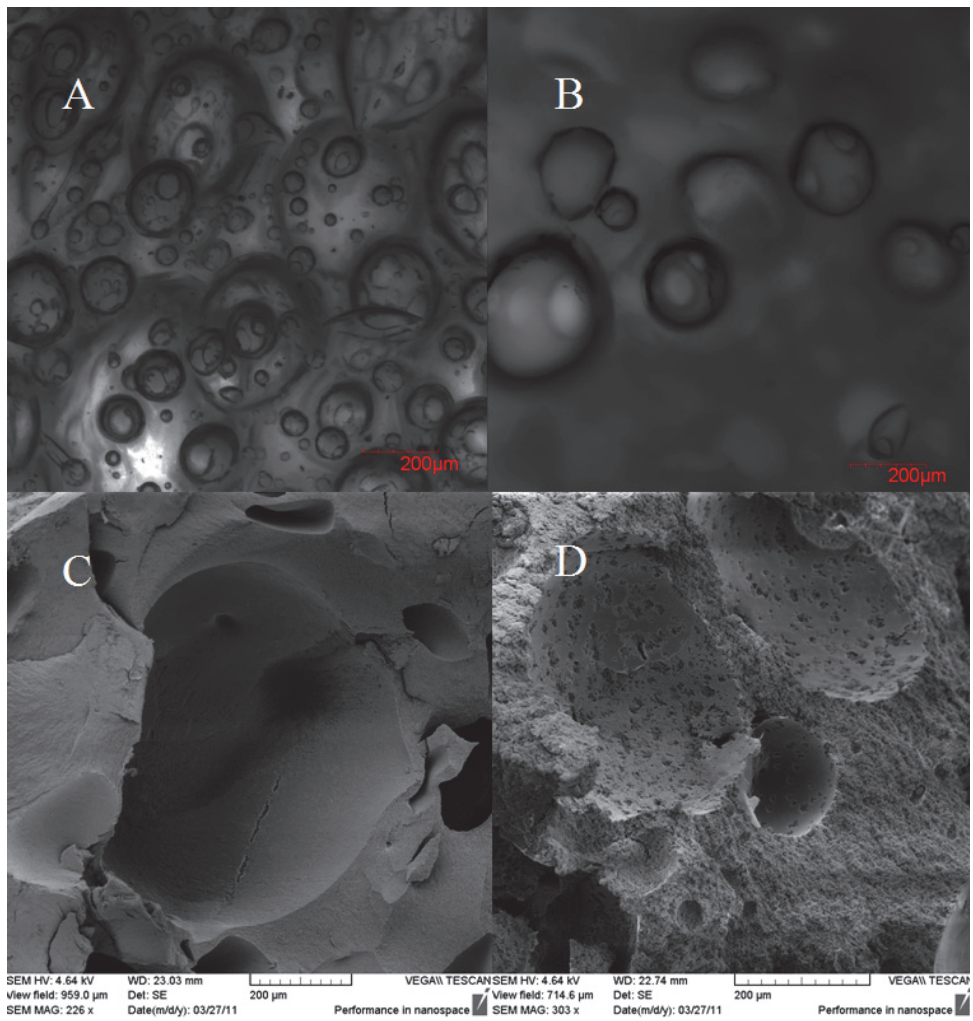

Fig. 2. Microstructure of aerated gel obtained by $10 \mathrm{mM}$ iron(II) or $30 \mathrm{mM}$ magnesium ion addition. A: LCSM: $10 \mathrm{mM} \mathrm{Fe}(\mathrm{II}), 7.5 \%$ protein concentration, $\mathrm{pH}$ 6.68; B: LCSM: $30 \mathrm{mM} \mathrm{Mg}, 7.0 \%$ protein concentration, $\mathrm{pH}$ 7.34; C: SEM: $10 \mathrm{mM} \mathrm{Fe}(\mathrm{II}), 7.5 \%$ protein concentration, $\mathrm{pH}$ 6.68; D: SEM: $30 \mathrm{mM} \mathrm{Mg}, 7.0 \%$ protein concentration, $\mathrm{pH} 7.34$.

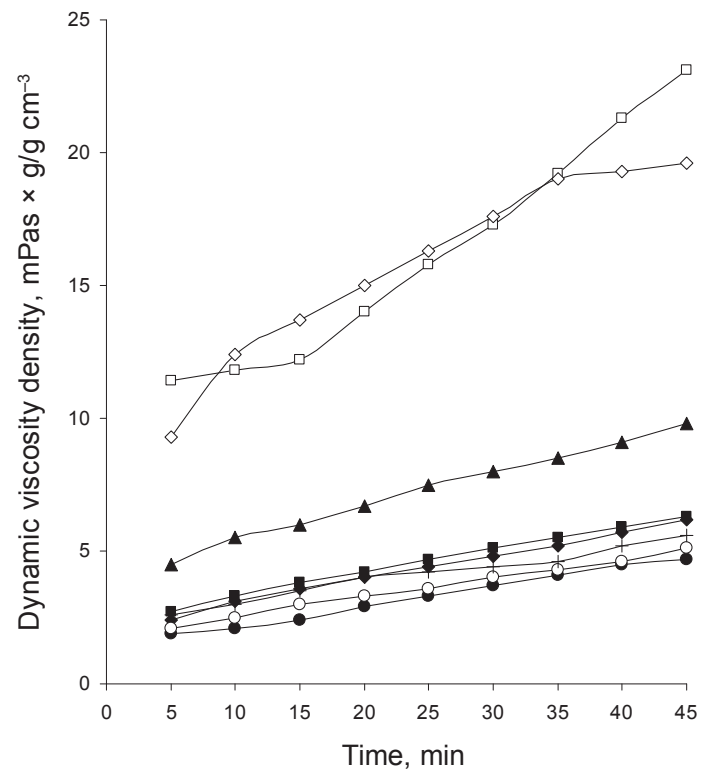

Fig. 3. Gelation process of $\mathrm{Fe}(\mathrm{II})$ or $\mathrm{Mg}$ induced gel obtained at different conditions monitored by an ultrasound viscometer.

๑: $\mathrm{Fe}(\mathrm{II}), 7.0 \%$ protein, $\mathrm{pH} 6.68$;

口: $\mathrm{Fe}(\mathrm{II}), 7.5 \%$ protein, $\mathrm{pH} 6.68$;

$\checkmark$ : $\mathrm{Fe}(\mathrm{II}), 8.0 \%$ protein, $\mathrm{pH} 6.68$;

O: $\mathrm{Mg}(\mathrm{II}), 6.0 \%$ protein, $\mathrm{pH} 7.73$;

$\square: \mathrm{Mg}(\mathrm{II}), 7.0 \%$ protein, $\mathrm{pH} 6.68$;

$\diamond: \mathrm{Mg}(\mathrm{II}), 7.0 \%$ protein, $\mathrm{pH} 7.73$;

+: $\mathrm{Mg}(\mathrm{II}), 7.0 \%$ protein, $\mathrm{pH} 8.00$;

А: $\mathrm{Mg}(\mathrm{II}), 8.0 \%$ protein, $\mathrm{pH} 7.73$ 


\section{Conclusion}

Addition of magnesium and iron(II) ions to pre-heated whey protein dispersions together with aeration process enables us to produce aerated gels with different microstructure and textural properties. The aeration process decreases hardness. In some cases texture parameters correlated with the viscosity measured using an ultrasound viscometer. These gels could be applied as matrices for food applications or to controlled release of active ingredients.

Research was supported by the National Science Centre, Kraków, Poland - Grant No. 2011/01/N/NZ9/04563.

\section{References}

Barbut, S. \& Foegeding, E.A. (1993): $\mathrm{Ca}^{2+}$-induced gelation of pre-heated whey protein isolate. J. Fd Sci., 58, 867-871.

Bryant, C. \& McClements, D. (1998): Molecular basis of protein functionality with special consideration of coldset gels derived from heat-denatured whey. Trends Fd Sci. Tech., 9, 143-151.

Da Silva, M.V. \& Delgado, J.M.P.Q. (2009): Cold-set whey protein isolate gels prepared with $\mathrm{Mg}^{2+}$ : denaturing conditions and phase diagram. Defect Diffus. Forum, 286, 559-564.

FoEgEding, E.A. (2007): Rheology and sensory texture of biopolymer gels. Curr. Opin. Colloid In., 12, $242-250$.

Foegeding, E.A. Bowland, E.L. \& Hardin, C.C. (1990): Factors that determine the fracture properties and microstructure of globular protein gels. Fd Hydrocoll., 9, 237-249.

Foegeding, E.A., Davis, J.P., Doucet, D. \& McGuffey, M.K. (2002): Advances in modifying and understanding whey protein functionality. Trends Fd Sci. Technol., 13, 151-159.

Gustaw, W. (2008): Production and rheological properties of whey protein-polysaccharide mixed (composites) gels. Acta Alimentaria, 37, 359-365.

Mleko, S., Tomczyńska-Mleko, M. \& TARgoński, Z. (2010): Globular protein gels as carriers of active substances. Agro Fd Ind. Hi-Tec., 21, 26-28.

Remondetto, G.E., Paquin, P. \& Subirade, M. (2002): Cold gelation of b-lactoglobulin in the presence of iron. J. Fd Sci., 67, 586-595.

Remondetto, G.E. \& Subirade, M. (2003): Molecular mechanism of $\mathrm{Fe}^{2+}$-induced b-lactoglobulin cold gelation. Biopolymers, 69, 461-469.

Stading, M., Landton, M. \& Hermansson, A.M. (1995): Small and large deformation studies of protein gels. J. Rheol., 39, 1445-1450.

Tomczyńska-Mleko, M. (2009): A novel base for dairy products: foamed whey protein gels. Agro Food Ind. Hi-Tec, $20,40-42$.

TomczyŃska-Mleko, M. (2010): Aerated gels obtained from whey protein concentrate. Milchwissenschaft - Milk Sci. Int., 65, 180-183.

Tomczyńska-Mleko, M. (2012): Ion induced gelation of whey proteins as a new method to produce foamed globular protein gels. Milchwissenschaft-Milk Sci. Int., 67, 443-446. 